\title{
A PERSPECTIVE ON THERMAL ANNEALING OF REACTOR PRESSURE VESSEL MATERIALS FROM THE VIEWPOINT OF EXPERIMENTAL RESULTS*
}

\author{
Shafik K. Iskander, Mikhail A. Sokolov, $\uparrow$ \\ and Randy K. Nanstad \\ Metals and Ceramics Division \\ Oak Ridge National Laboratory \\ Oak Ridge, Tennessee 37831-6151
}

\begin{abstract}
* Research sponsored sponsored by the Office of Nuclear Regulatory Research, Division of Engineering Technology, U.S. Nuclear Regulatory Commission, under Interagency Agreement DOE 1886-8109-8L with the U.S. Department of Energy under contract DE-AC05-96OR22464 with Lockheed Martin Energy Research Corp.
\end{abstract}

†Postdoctoral Researcher.

DISTRIBUTION OF THIS DOCUMENT IS UNLIMITED

The submitted manuscript has been authored by a contractor of the U.S. Government under contract No. DE-ACO5-95OR22464. Accordingly. the U.S. Government retains a nonexclusive, royalhy-free ticense to publish or reproduce the pubished form of this contribution, or allow others to do so, for U.S. Govemment purposes.

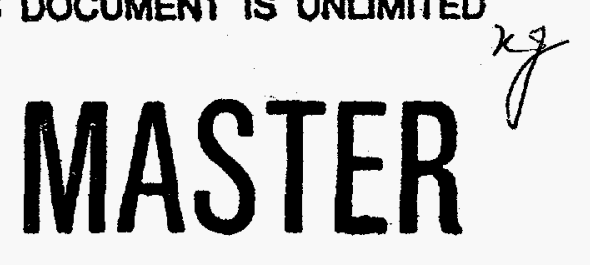

\section{DISCLAIMER}

This report was prepared as an account of work sponsored by an agency of the United States Government. Neither the United States Government nor any agency thereof, nor any of their employees, makes any warranty, express or implied, or assumes any legal liability or responsibility for the accuracy, completeness, or usefulness of any information, apparatus, product, or process disclosed, or represents that its use would not infringe privately owned rights. Reference herein to any specific commercial product; process, or service by trade name, trademark, manufacturer, or otherwise does not necessarily constitute or imply its endorsement, recommendation, or favoring by the United States Government or any agency thereof. The views and opinions of authors expressed herein do not necessarily state or reflect those of the United States Government or any agency thereof. 


\section{DISCLAIMER}

Portions of this document may be illegible in electronic image products. Images are produced from the best available original document. 


\title{
A PERSPECTIVE ON THERMAL ANNEALING OF REACTOR PRESSURE VESSEL MATERIALS FROM THE VIEWPOINT OF EXPERIMENTAL RESULTS
}

\author{
Shafik K. Iskander, Mikhail A. Sokolov, \\ and Randy K. Nanstad \\ Metals and Ceramics Division \\ Oak Ridge National Laboratory \\ Oak Ridge, Tennessee
}

\begin{abstract}
It is believed that in the next decade or so, several nuclear reactor pressure vessels (RPVs) may exceed the reference temperature limits set by the pressurized thermal shock screening criteria. One of the options to mitigate the effects of irradiation on RPVs is to thermally anneal them to restore the toughness properties that have been degraded by neutron irradiation. This paper summarizes recent experimental results from work performed at the Oak Ridge National Laboratory to study the annealing response, or "recovery" of several irradiated RPV steels. The fracture toughness is one of the important properties used in the evaluation of the integrity of RPVs. Optimally, the fracture toughness is measured directly by fracture toughness specimens, such as compact tension or precracked Charpy specimens, but is often inferred from the results of Charpy V-notch impact specimens. The experimental results are compared to the predictions of models for embrittlement recovery which have been developed by Eason et al. Some of the issues in annealing that still need to be resolved are discussed.
\end{abstract}

\section{NTRODUCTION}

Sorne early nuclear reactor pressure vessels (RPVs) fabricated from certain types of steels may not meet the regulatory requirements for fracture toughness as they near their end of life. These regulatory requirements are promulgated in Appendix G of "Title 10," Part 50 of the Cade of Federal Regulations (10CFRSO). It is believed that in the next docade or so, several vessels may exceed the limits set by the pressurized thermal shock reference temperature (10CFR50.61). In that case, thermal annealing of the RPV may mitigate the effects of neutron embrittlement on fracture toughness. A dozen or so RPVs have aiready been thermally annealed in Eastern Europe (Rogov and Morozov, 1994) and a U.S. utility is contemplating annealing an RPV.

Proposed Rules issued by the U.S. Nuclear Regulatory Commission (NRC) in October 1994 to amend 10CFR50 include the "Thermal
Annealing Rule," which provides new requirements for thermal annealing an RPV to mitigate the effects of neutron irradiation (10CFR50.66). The rule states that "two items of particular importance to the overall annealing are the recovery of fracture toughness and the rate of reembrittlement of the RPV beltine materials." These two items form the principal objectives of research performed at the Oak Ridge National Laboratory (ORNL). This research is performed within the NRC-sponsored Heavy Section Steel Irradiation (HSSD) Program. Several RPV materials which are most likely to be annealed are being investigated, and their fracture toughness recovery and the reembrittlement rate of the fracture toughness will be correlated to the corresponding rates of the Charpy $V$-notch (CVN) specimen recovery and reembrittlement. The rate of reembrittlement is an important consideration since it will determine how long the plant may be safely operated after it is annealed.

Historically, the toughness of RPVs has been monitored through surveillance programs in which predominantly CVN specimens are placed in capsules, withdrawn and tested periodically. The degradation of fracture toughness is estimated from both the radiation-induced shift of the CVN 41-J (30-ft-lb) transition temperature $\left(\Delta T T_{j}\right)$ as well as the decrease in the upper-shelf energy (USE). The fracture toughnesses of irradiated RPV material are estimated from the American Society of Mechanical Engineers (ASME) Boiler and Pressure Vessel Code fracture toughness curves by shifting them upward in temperature by $\Delta T_{i}$, (which is also referred to as the shift in the reference temperature, $\left.\mathbf{R T}_{\mathbf{N O T}}\right)$. The value of the unirradiated $\mathbf{R T}_{\text {NoT }}$ is based on both the drop-weight nil-ductility transition temperature and results of testing Charpy specimens. However, the shift of the fracture toughness curves is based solely on the Charpy $\Delta T T_{i}$. Recent advances in fracture mechanics may allow the direct determination of the fracture toughness and shift in the transition region of thick-section RPV stecls from relatively small fracture toughness specimens, but, for some of the earlier RPVs, the use of CVN-based surveillance data and specimens will probably play a key role in the judgement of the 
eficacy of the anneal. This paper discusses the effect of annealing on the CVN impact energy and fracture toughness of several irradiated RPV muterials; a few general conclusions ure drawn.

\section{DESCRIPTION OF MATERIAL USED}

The commercially fabricated submerged arc-welds and plate used in this study are commonly used in RPVs. These materials have been extensively characterized in their unirradiated and irradiated conditions (Nanstad et al., 1990, 1992), (Stelaman et al., 1985). The chemical composition and mechanical properties of the materials investigated have been summarized in Tables 1 and 2, respectively. Large variations in the copper content (from 0.21 to $0.46 \%$ ) have been observed in welds fabricated using weld wire with copper costing (Nanstad et al., 1992). To avoid these large variations, the 73W weld wire was fabricated with copper added to the melt, consequently this weld has a very small standard deviation in copper content of $0.010 \%$.

The "undersize" 73W CVN specimens used in part of this study were slightly smaller in one cross-sectional dimension than standard full-size CVN specimens. The dimension normal to the notch of the "undersize" CVN spocimens is $95 \%$ of the full-size specimens and, for comparison to the full-size specimens the results have been normalized as described below. This slightly smaller dimension of the specimens was dictated by the space available in the HSSI Fifth Irradiation Series capsoules (Mriler a al, 1988). The difference in the unirradiated CVN 41-J (30-ft-lb) transition temperatures between the full-size and subsize specimens is insignificant, but the USE of the subsize specimen is $87 \%$ of that of the full-size specimen (see Table 2). The subsize $73 \mathrm{~W}$ CVN specimens were irradiated to average exposures of $1.8 \times 10^{19}$ neutrons $/ \mathrm{cm}^{2}(>1 \mathrm{MeV}), 1.1 \times 10^{20}$ neutrons $/ \mathrm{cm}^{2}$ $(0.1 \mathrm{MeV}$ ), and 0.040 displacements per atom. The irradiation was performed in the Oak Ridge Research Reactor for $1450 \mathrm{~h}$ at an average flux of $3 \times 10^{12}$ neutrons $/\left(\mathrm{cm}^{2}-8\right)(>1 \mathrm{MeV}$ ) (Miller et al., 1988). The rest of the materials were irradiated for $3596 \mathrm{~h}$ at an average flux of $8 \times 10^{11}$ neutrons $\left(\mathrm{cm}^{2}-\mathrm{s}\right)(>1 \mathrm{MeV})$ to an average fluence of $1 \times 10^{19}$ neutrons $/ \mathrm{cm}^{2}(>1 \mathrm{MeV})$ in the Ford Nuclear Reactor at the University of Michigan. For the range of fluences and fluxes of this study, the influence of fluence and flux on the percent recovery of CVN properties is probably of secondary importance compared to the effect of material chemistry, annealing temperature, and time. The nominal irradiation temperature for all materials was $288^{\circ} \mathrm{C}$.

\section{ANNEALNG TEMPERATURE AND TIMES INVESTIGATED}

The irradiated specimens were annealed at 343 and $454^{\circ} \mathrm{C}$ (650 and $850^{\circ} \mathrm{F}$. These two temperatures have been often investigated as approximate lower and upper bounds of probable annealing temperatures (Major and Lott, 1989). The $343^{\circ} \mathrm{C}$ temperature could be used for a wet anneel. This is considerably simpler to perform than a dry anneal at $454^{\circ} \mathrm{C}$, since the reactor internals would not have to be removed. One annealing time of $168 \mathrm{~h}$ was investigated at the $343^{\circ} \mathrm{C}$ temperature. In the case of the HSSI $73 \mathrm{~W}$ weld, four annealing times varying from 1 day to 2 weeks ( $336 \mathrm{~h}$ ) were investigated at a temperature of $454^{\circ} \mathrm{C}$. The rest of the materials were annealed at the two temperatures mentioned for $168 \mathrm{~h}$.

\section{RESULTS AND DISCUSSION}

The recovery of CVN impact properties as a result of annealing is typically measured by the changes in values of the Charpy USE and the 41-J transition temperature, TT, and are defined below. The values of the USE and TT were calculated from a nonlinear regression fit of a hyperbolic tangent equation to the CVN impact energy results. The hyperbolic tangent equation is of the form:

$$
E=\frac{U S E+L S E}{2}+\frac{U S E-L S E}{2} \operatorname{Tanh}\left(\frac{T-M T T}{T Z W / 2}\right) .
$$

where

$$
\begin{aligned}
\text { E } & =\text { impact energy } \\
\text { USE and LSE } & =\text { upper- and lower-shelf energy values, } \\
T & =\text { respectively, } \\
\text { MTT } & =\text { mid-transition temperature, } \\
T 2 W & =\text { transition zone width. }
\end{aligned}
$$

The ISE was prescribed to be $2.7 \mathrm{~J}$, the average value obtained from tests of five CVN apecimens from a submerged-are weld at liquid nitrogen temperature of $-196^{\circ} \mathrm{C}$ (Nanstad et al., 1992). The USE, MTT, and TZW are fitting parameters.

The percent recovery of the $\Delta T T_{i}$ and USE are referenced to the shift or drop, respectively, due to neutron irradiation. A $100 \%$ recovery would indicate that the values of $T_{i}$ and $U S E$ after annealing have fully recovered their unirradiated values. The percent recovery of the $T_{i}$ is defined as the ratio of the residual transition temperature shift after annealing to the shift due to irradiation, $\Delta T_{i}$ $=\mathrm{TT}_{\mathrm{i}}-\mathrm{TT}_{\text {mim }}$ or.

$$
\text { \% Recovery } \mathrm{Tr}_{\mathrm{in}}=\frac{\mathrm{TT}_{\mathrm{i}}-\mathrm{TT}_{\mathrm{i}}}{\mathrm{TT}_{\mathrm{i}}-\mathrm{TT}_{\text {min }}} \cdot 100,
$$

where $\mathrm{TT}$ is the transition temperature at the 41-J energy level for the condition indicated by outer subscript. The percent recovery of the USE is defined in an analogous manner to Eq. (2):

$$
\% \text { Recovery USE }_{-}=\frac{\text { USE }_{\mathrm{i}}-\mathrm{USE}_{\mathrm{i}}}{\mathrm{USE}_{\operatorname{mi}}-\mathrm{USE}_{\mathrm{i}}} \cdot 100
$$

A representative test result from testing the undersize HSSI weld $73 \mathrm{~W}$ Charpy specimens is shown in Fig. 1 , in which the impact energy is shown as a function of temperature. The symbols are the experimental results for each specimen tested, and the three curves shown are the least squares mean fits of Eq. (1) to the experimental results. Also shown are the drops in USE and $\Delta T T_{i}$, as well as the recoveries computed from Eqs. (2) and (3). The values used in either equation are those calculated from the mean curves. More details of the results of testing the undersize specimens from HSSI weld $73 \mathrm{~W}$ may be found elsewhere (Iskander et al., 1996).

Irradiated $=\mathrm{i}$, annealed $=\mathrm{a}$, unirradiated = unirr, and irradiated and annealed $=$ ia. 
Table 1. Average chemical composition of materials used in the annealing studies

\begin{tabular}{|l|c|c|c|c|c|c|c|c|c|c|}
\hline \multirow{2}{*}{ Material } & \multicolumn{10}{|c|}{$\begin{array}{c}\text { Composition } \\
\text { (wt \%) }\end{array}$} \\
\cline { 2 - 10 } & $\mathrm{C}$ & $\mathrm{Mn}$ & $\mathrm{P}$ & $\mathrm{S}$ & $\mathrm{Si}$ & $\mathrm{Cr}$ & $\mathrm{Ni}$ & $\mathrm{Mo}$ & $\mathrm{Cu}$ & $\mathrm{V}$ \\
\hline HSSI weld 73W & 0.098 & 1.56 & 0.005 & 0.005 & 0.45 & 0.25 & 0.60 & 0.58 & 0.31 & 0.003 \\
$\begin{array}{l}\text { Midland beltline } \\
\text { weld }\end{array}$ & 0.084 & 1.61 & 0.017 & 0.007 & 0.62 & 0.10 & 0.57 & 0.41 & 0.21. & 0.004 \\
$\begin{array}{l}\text { Midland nozzle } \\
\text { weld }\end{array}$ & 0.088 & 1.57 & 0.015 & 0.010 & 0.56 & 0.11 & 0.58 & 0.39 & 0.37. & 0.008 \\
HSST Plate 02 & 0.23 & 1.55 & 0.009 & 0.014 & 0.20 & 0.04 & 0.67 & 0.53 & 0.14 & 0.003 \\
\hline
\end{tabular}

Table 2. Mechanical properties of materials used

\begin{tabular}{|l|c|c|c|c|}
\hline \multicolumn{1}{|c|}{ Material } & \multirow{1}{*}{$\begin{array}{c}\text { CVN impact } \\
\text { USE } \\
\text { (J) }\end{array}$} & $\begin{array}{c}\text { CVN 41-J } \\
\text { transition } \\
\text { temperature } \\
\left({ }^{\circ} \mathrm{C}\right)\end{array}$ & \multicolumn{2}{|c|}{$\begin{array}{c}\text { Room temperature tensile strength } \\
\text { (MPa) }\end{array}$} \\
\cline { 4 - 5 } & 118 & -38 & 495 & 603 \\
\hline $\begin{array}{l}\text { HSSI weld 73W } \\
\text { (undersize) }\end{array}$ & 135 & -40 & 495 & 603 \\
$\begin{array}{l}\text { HSSI weld 73W } \\
\text { (full size) }\end{array}$ & 89 & -9 & 407 & 586 \\
Midland beltline weld & 88 & -1 & 505 & 655 \\
Midland nozzle weld & 164 & -16 & 471 & 619 \\
\hline
\end{tabular}


One of the results of this investigation is that annealing "overrecovered" or increased the USE to values greater than the unirradiated specimens. This was not unexpected since other invertigators have also noted such an effect. Annealing, tempering and aging effects are diffusion processes where temperature is the daminant parameter and time is of secondary influence. As part of the original fabrication procedure, the HSSI $73 \mathrm{~W}$ weld was postweld heat-treated at a temperature of $607^{\circ} \mathrm{C}\left(1125^{\circ} \mathrm{F}\right)$ for $40 \mathrm{~h}$, and thus further exposure at the lower temperature of $454^{\circ} \mathrm{C}$ for $168 \mathrm{~h}$ would not be expected to have any effect. To determine whether this increase in USE was due to irradiation, unirradiated specimens were also aged at 460 and $490^{\circ} \mathrm{C}$ for $168 \mathrm{~h}$, and the USE increased $117 \%$. The reasons for this phenomenon are being investigated.

In the case of toughness testing in the transition temperature range, the following relationship between the modian fracture toughness in the transition region, $\mathbf{K}_{\text {tocody }}$ and temperature is used:

$$
\boldsymbol{K}_{\mathrm{J}(\bmod )}=30+70 \exp \left[0.019\left(\mathrm{~T}-\mathrm{T}_{0}\right)\right] \text {, }
$$

where $T_{0}$ is a parameter, which together with $K_{\text {sotand }}$ are obtained using procedures that are in the process of being developed into an ASTM standard* (Wallin, 1989, McCabe et al, 1994). The differences between the respective $T_{0} s$ are used as measures of the efiect of annealing. A typical result from such testing is shown in Fig. 2 , which shows three $K_{\text {tefen }}$ curves for each of the unirradiated, irradiated, and annealed conditions. Detailed results have or will be published (Sokolov et al., 1995; Sokolov et al., 1996).

The TT and USE of the various materials and for the conditions investigated are given in Tables 3 and 4 , respectively. The $\Delta T T_{i}$, and the percent recovery of the $\Delta T_{i}$ have been plotted in Figs. 3 and 4. The figures show that in general, the values of $\mathrm{TT}_{\mathrm{i}}$ and the percent recovery depend strongly on the annealing temperature, and to a lesser degree on annealing time. This trend is illustrated by the annealing behavior of the specimens from HSSI weld $73 \mathrm{~W}$ that has a recovery of $\mathrm{TT}_{\mathrm{i}}$ that is insignificant for annealing at $343^{\circ} \mathrm{C}$ for $168 \mathrm{~h}$, but is over $90 \%$ when annealed at $454^{\circ} \mathrm{C}$ for the same length of time. Increasing the annealing times from 96 to 168 to $336 \mathrm{~h}$ did not cause an appreciable gain in recovery. However, the degree of recovery of the Midland weld (MW) and Heavy-Section Steel Technology (HSST) Plate 02 materials due to annealing at $343^{\circ} \mathrm{C}$ for $168 \mathrm{~h}$ was approximately 49 and $36 \%$, respectively, which is substantially greater than the $10 \%$ of the specimens from HSSI weld $73 \mathrm{~W}$. Thus this could be a viable annealing temperature for such materials.

The response of the USE to annealing, Figs. 5 and 6, is different than that of the $\mathrm{TT}_{i}$ in the following aspects. The percent recovery of the USE is substantial for all conditions investigated, and, in many cases, the USE overrecovers to values greater than the unirradiated value. Even for the $343^{\circ} \mathrm{C} / 168-\mathrm{h}$ anneal, the materials that

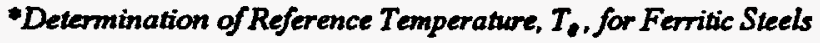
in the Transition Range, Draft 11, Task Group E08.08.03 on Ductile-Brittle Transition, American Socicty for Testing and Materials, 1995. experienced a substantial recovery in $\mathrm{TT}_{1}$ also recovered over $100 \%$ of the drop in USE due to irradiation. Although the mechanisms involved in the recovery of the USE and $\mathrm{TT}_{1}$ may be different, such a response suggests that there may be a relationship between them.

Figures 5 and 6 also show that using the definition of the percent recovery of USE given by Eq. 3 (analogous to the definition of the percent recovery of the $\mathrm{TT}_{412}$ ) can lead to values of recovery ranging from 200 to $300 \%$, which can be misleading unless Eq. 3 is kept in mind. An alternate definition of the fractional recovery is one that compares the value of the USE to the unirradiated value as follows:

$$
\% \text { Recovery USE }=\frac{\mathrm{USE}^{\prime}}{\mathrm{USE}_{\text {urix }}} \cdot 100,
$$

where USE' is the USE for the condition studied. Note that since it is not based on irradiated values, it can be used to compare changes in USE due to aging as well as to changes due to irradiation and annealing. However, if an irradiated USE does not recover, it still indicates a misleading "recovery," equal in value to the decrease in USE due to irradiation. Thus, cach of these definitions has advantages and disadvantages. Besides yielding values such as those mentioned above, Eq. (3) is based on the drop in USE. The drop in USE due to irradiation for the Midland beltline weld is approximately $6 \mathrm{~J}$, which is of the same order of magnitude as the scatter. Relatively small gains in USE could lead to USE recovery values of $300 \%$. One advantage of the definition given by Eq. (3) is that it is analogous to that for the recovery of the transition temperature, and thus the corresponding recoveries can be compared. The advantage of Eq. (5) is that the recovery of the USE mentioned above, instead of being reported as $300 \%$, would be indicated as $120 \%$.

Preliminary fracture toughness results from testing compact and precracked Charpy specimens of irradiated RPV steels annealed at $454^{\circ} \mathrm{C}$ for $168 \mathrm{~h}$ show similar trends as those obtained in testing Charpy impact specimens (Sokolov et al., 1995, 1996). Recovery depends strongly upon annealing temperature and the measure of fracture toughness. The recovery of the cleavage fracture toughness in the transition region as indicated by the $T$, temperature is partial, but the tearing modulus and the ductile fracture toughness as indicated by $J_{k}$ have either fully recovered or overrecovered. The investigation of the relationship of recovery of the fracture toughness to that of the Charpy properties is still under investigation.

\section{PREDICTION OF RECOVERY}

Models developed by Eason et al., 1995, give the following relationship for the recovery of the transition temperature:

$$
\mathrm{TT}_{\mathrm{in}}=\mathrm{TT}_{\mathrm{i}}-\Delta \mathrm{TT}_{\mathrm{i}}\left[0.5+0.5 \tanh \left(\frac{\mathrm{a}_{1} \mathrm{~T}_{\mathrm{i}}-\mathrm{a}_{2}}{95.7}\right)\right],
$$

where $T T$ is the transition temperature, in ${ }^{\circ} \mathrm{F}$, for the condition indicated by the subecript, irradiated, $i$, irradiated and annealed, ia, and $\Delta T_{i}$ is the shift due to irradiation, all temperatures are in ${ }^{\circ} \mathrm{F}$, and 


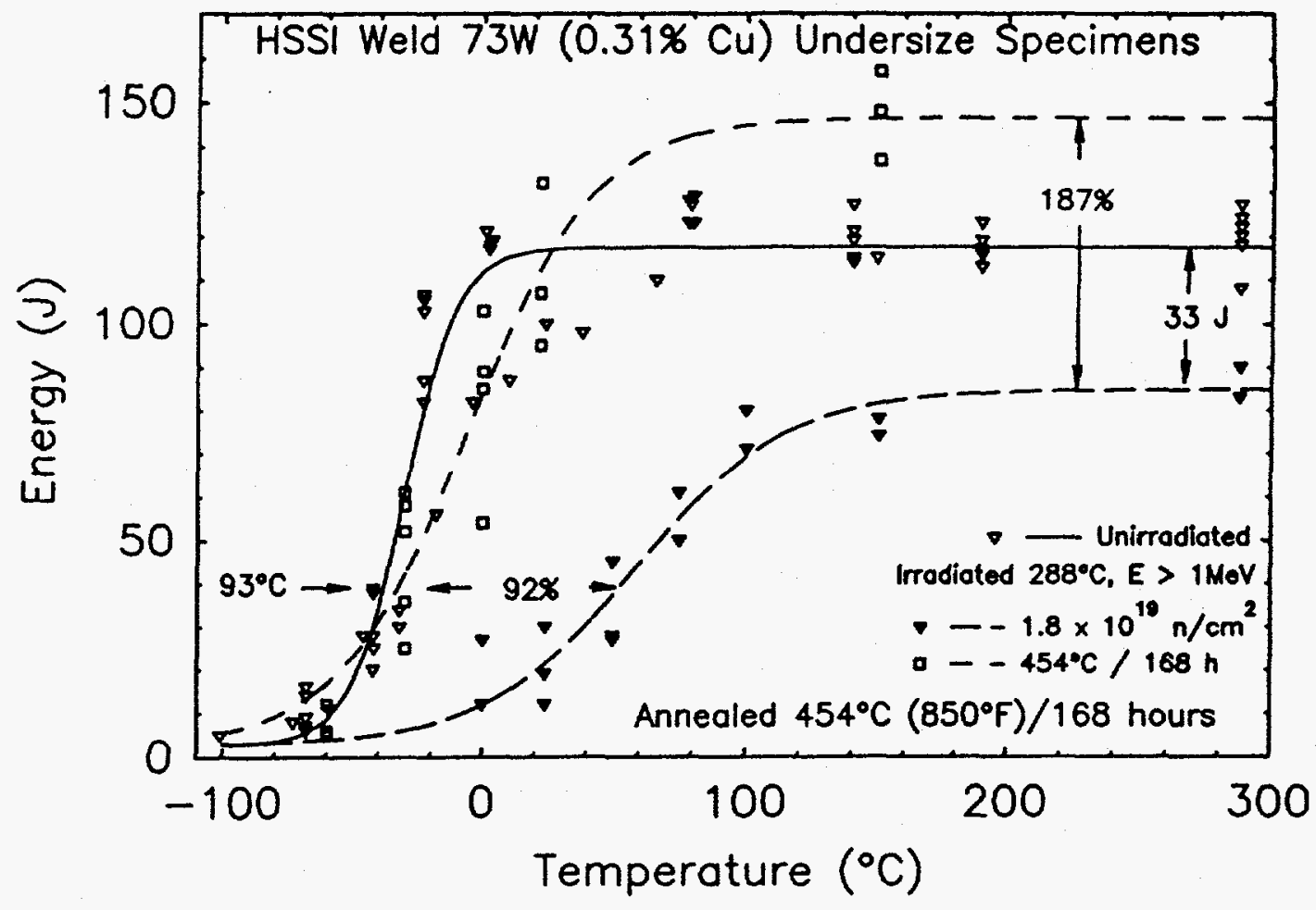

Fig. 1. Charpy energy of HSSI weld $73 \mathrm{~W}$ in the unirradiated, irradiated, and annealed conditions. The irradiated specimens were annealed at $454^{\circ} \mathrm{C}$ for $168 \mathrm{~h}$.

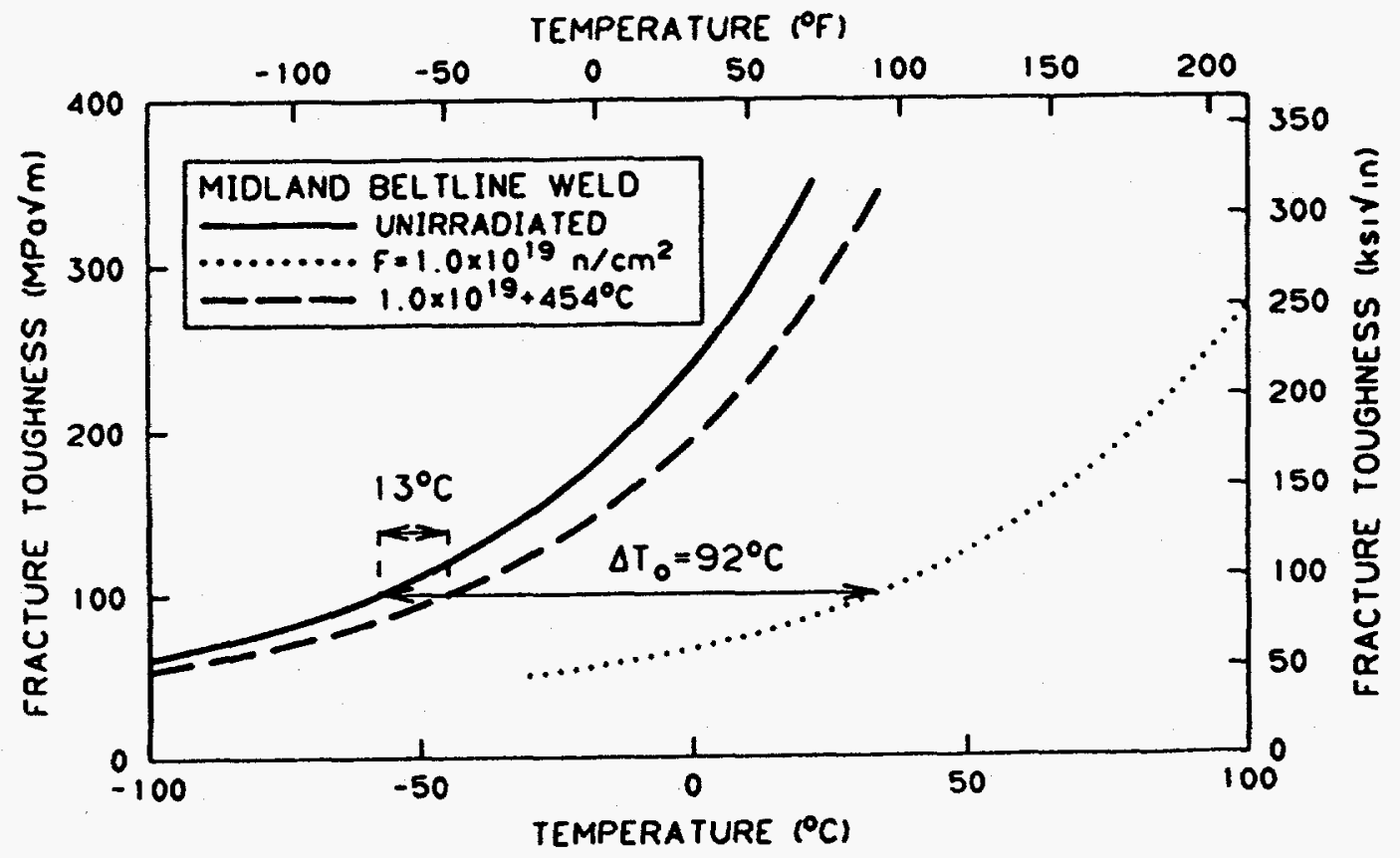

Fig. 2. Median fracture toughness of Midland beltline weld in the unirradiated, irradiated, and irradiated/annealed conditions. The irradiated specimens were annealed at $454^{\circ} \mathrm{C}$ for $168 \mathrm{~h}$. 
Table 3. Transition temperature of materials investigated in the unirradiated, irradiated, and irradiated/annealed conditions

\begin{tabular}{|c|c|c|c|c|c|}
\hline $\begin{array}{l}\text { Material } \\
\text { condition }\end{array}$ & $\begin{array}{l}\text { Annealing } \\
\text { temperature } \\
\left({ }^{\circ} \mathrm{C}\right)\end{array}$ & $\begin{array}{l}\text { Annealing } \\
\text { time } \\
\text { (h) }\end{array}$ & $\begin{array}{l}\text { Experimental } \\
\mathrm{TT}_{41-1} \\
\left({ }^{\circ} \mathrm{C}\right)\end{array}$ & $\begin{array}{c}\text { Predicted } \\
\text { [Eqs. (6)-(9)] } \\
\left({ }^{\circ} \mathrm{C}\right)\end{array}$ & $\begin{array}{c}\text { Difference } \\
\text { (predicted - } \\
\text { experimental') } \\
\left({ }^{\circ} \mathrm{C}\right)\end{array}$ \\
\hline \multicolumn{6}{|c|}{$73 \mathrm{~W}$ undersize, $0.31 \% \mathrm{Cu}$, irradiated $1.8 \times 10^{19} \mathrm{n} / \mathrm{cm}^{2}$ at a flux of $3 \times 10^{12} \mathrm{n} /\left(\mathrm{cm}^{2} \cdot \mathrm{s}\right)(>1 \mathrm{MeV})$} \\
\hline $\begin{array}{l}\text { Unirradiated } \\
\text { Irradiated } \\
\text { Irradiated/annealed } \\
\text { Irradiated/annealed } \\
\text { Irradiated/annealed } \\
\text { Irradiated/annealed } \\
\text { Irradiated/annealed }\end{array}$ & $\begin{array}{l}343 \\
454 \\
454 \\
454 \\
454\end{array}$ & $\begin{array}{r}168 \\
24 \\
96 \\
168 \\
336 \\
\end{array}$ & $\begin{array}{r}-38 \\
55 \\
46 \\
-7 \\
-25 \\
-31 \\
-34\end{array}$ & $\begin{array}{r}36 \\
-9 \\
-16 \\
-18 \\
-21\end{array}$ & $\begin{array}{r}-10 \\
-2 \\
9 \\
13 \\
13\end{array}$ \\
\hline \multicolumn{6}{|c|}{$73 \mathrm{~W}$ full size, $0.31 \% \mathrm{Cu}$, irradiated $1 \times 10^{19} \mathrm{n} / \mathrm{cm}^{2}$ at a flux of $8 \times 10^{11} \mathrm{n} /\left(\mathrm{cm}^{2} \cdot \mathrm{s}\right)(>1 \mathrm{MeV})$} \\
\hline $\begin{array}{l}\text { Unirradiated } \\
\text { Irradiated } \\
\text { Irradiated/annealed }\end{array}$ & 343 & 168 & $\begin{array}{r}-40 \\
40 \\
26\end{array}$ & 29 & 3 \\
\hline \multicolumn{6}{|c|}{ Midland beltline weld, $0.21-0.34 \% \mathrm{Cu}$, irradiated $1 \times 10^{19} \mathrm{n} / \mathrm{cm}^{2}$ at a flux of $8 \times 10^{11} \mathrm{n} /\left(\mathrm{cm}^{2} \cdot \mathrm{s}\right)(>1 \mathrm{MeV})$} \\
\hline $\begin{array}{l}\text { Unirradiated } \\
\text { Irradiated } \\
\text { Irradiated/annealed } \\
\text { Irradiated/annealed }\end{array}$ & $\begin{array}{l}343 \\
454\end{array}$ & $\begin{array}{l}168 \\
168\end{array}$ & $\begin{array}{l}-9 \\
95 \\
44 \\
15\end{array}$ & $\begin{array}{l}74 \text { to } 81 \\
3 \text { to } 13\end{array}$ & $\begin{array}{c}30 \text { to } 37 \\
-12 \text { to }-2\end{array}$ \\
\hline \multicolumn{6}{|c|}{ Midland nozzle weld, $0.37-0.46 \% \mathrm{Cu}$, irradiated $1 \times 10^{19} \mathrm{n} / \mathrm{cm}^{2}$ at a flux of $8 \times 10^{11} \mathrm{n} /\left(\mathrm{cm}^{2} \cdot \mathrm{s}\right)(>1 \mathrm{MeV})$} \\
\hline $\begin{array}{l}\text { Unirradiated } \\
\text { Irradiated } \\
\text { Irradiated/annealed }\end{array}$ & 454 & 168 & $\begin{array}{l}-1 \\
90 \\
31\end{array}$ & 18 & -13 \\
\hline \multicolumn{6}{|c|}{ HSST Plate $02,0.14 \% \mathrm{Cu}$, irradiated $1 \times 10^{19} \mathrm{n} / \mathrm{cm}^{2}$ at a flux of $6.43 \times 10^{11} \mathrm{n} /\left(\mathrm{cm}^{2} \cdot \mathrm{s}\right)(>1 \mathrm{MeV})$} \\
\hline $\begin{array}{l}\text { Unirradiated, L-T } \\
\text { Irradiated, estimated } \\
\text { Irradiated/annealed, L-T } \\
\text { Irradiated/annealed, L-T }\end{array}$ & $\begin{array}{l}343 \\
454\end{array}$ & $\begin{array}{l}168 \\
168\end{array}$ & $\begin{array}{r}-16 \\
39 \\
19 \\
-10\end{array}$ & $\begin{array}{r}25 \\
-12\end{array}$ & $\begin{array}{r}6 \\
-2\end{array}$ \\
\hline
\end{tabular}


Table 4. Upper-shelf energy of materials investigated in the unirradiated, irradiated, and irradiated/annealed conditions

\begin{tabular}{|c|c|c|c|c|c|}
\hline $\begin{array}{l}\text { Material } \\
\text { condition }\end{array}$ & $\begin{array}{l}\text { Annealing } \\
\text { temperature } \\
\left({ }^{\circ} \mathrm{C}\right)\end{array}$ & $\begin{array}{l}\text { Annealing } \\
\text { time } \\
\text { (h) }\end{array}$ & $\begin{array}{l}\text { Experimental } \\
\text { upper-shelf } \\
\text { value } \\
\text { (ग) }\end{array}$ & $\begin{array}{l}\text { Predicted } \\
\text { [Eq. (10)] } \\
\text { (J) }\end{array}$ & $\begin{array}{c}\text { Difference } \\
\text { (predicted - } \\
\text { experimental') } \\
(J)\end{array}$ \\
\hline \multicolumn{6}{|c|}{$73 \mathrm{~W}$ undersize, $0.31 \% \mathrm{Cu}$, irradiated $1.8 \times 10^{19} \mathrm{n} / \mathrm{cm}^{2}$ at a flux of $3 \times 10^{12} \mathrm{n} /\left(\mathrm{cm}^{2} \cdot \mathrm{s}\right)(>1 \mathrm{MeV})$} \\
\hline $\begin{array}{l}\text { Unirradiated } \\
\text { Irradiated } \\
\text { Irradiated/annealed } \\
\text { Irradiated/annealed } \\
\text { Irradiated/annealed } \\
\text { Irradiated/annealed } \\
\text { Irradiated/annealed }\end{array}$ & $\begin{array}{l}343 \\
454 \\
454 \\
454 \\
454\end{array}$ & $\begin{array}{r}168 \\
24 \\
96 \\
168 \\
336\end{array}$ & $\begin{array}{r}118 \\
85 \\
99 \\
128 \\
130 \\
147 \\
154\end{array}$ & $\begin{array}{l}103 \\
119 \\
124 \\
124 \\
124\end{array}$ & $\begin{array}{r}4 \\
-10 \\
-6 \\
-23 \\
-30\end{array}$ \\
\hline \multicolumn{6}{|c|}{$73 \mathrm{~W}$ full size, $0.31 \% \mathrm{Cu}$, irradiated $1 \times 10^{19} \mathrm{n} / \mathrm{cm}^{2}$ at a flux of $8 \times 10^{11} \mathrm{n} /\left(\mathrm{cm}^{2} \cdot \mathrm{s}\right)(>1 \mathrm{MeV})$} \\
\hline $\begin{array}{l}\text { Unirradiated } \\
\text { Irradiated } \\
\text { Irradiated/annealed }\end{array}$ & 343 & 168 & $\begin{array}{r}135 \\
99 \\
124\end{array}$ & 119 & -5 \\
\hline \multicolumn{6}{|c|}{ Midland beltline weld, $0.21-0.34 \% \mathrm{Cu}$, irradiated $1 \times 10^{19} \mathrm{n} / \mathrm{cm}^{2}$ at a flux of $8 \times 10^{11} \mathrm{n} /\left(\mathrm{cm}^{2} \cdot \mathrm{s}\right)(>1 \mathrm{MeV})$} \\
\hline $\begin{array}{l}\text { Unirradiated } \\
\text { Irradiated } \\
\text { Irradiated/annealed } \\
\text { Irradiated/annealed }\end{array}$ & $\begin{array}{l}343 \\
454 \\
\end{array}$ & $\begin{array}{l}168 \\
168\end{array}$ & $\begin{array}{r}89 \\
80 \\
92 \\
106\end{array}$ & $\begin{array}{c}88 \text { to } 84 \\
105\end{array}$ & $\begin{array}{c}-3 \text { to }-8 \\
-1\end{array}$ \\
\hline \multicolumn{6}{|c|}{ Midland nozzle weld, $0.37-0.46 \% \mathrm{Cu}$, irradiated $1 \times 10^{19} \mathrm{n} / \mathrm{cm}^{2}$ at a flux of $8 \times 10^{11} \mathrm{n} /\left(\mathrm{cm}^{2} \cdot \mathrm{s}\right)(>1 \mathrm{MeV})$} \\
\hline $\begin{array}{l}\text { Unirradiated } \\
\text { Irradiated } \\
\text { Irradiated/annealed }\end{array}$ & 454 & 168 & $\begin{array}{r}88 \\
68 \\
105 \\
\end{array}$ & 103 & -2 \\
\hline \multicolumn{6}{|c|}{ HSST Plate $02,0.14 \% \mathrm{Cu}$, irradiated $1 \times 10^{19} \mathrm{n} / \mathrm{cm}^{2}$ at a flux of $8 \times 10^{11} \mathrm{n} /\left(\mathrm{cm}^{2} \cdot \mathrm{s}\right)(>1 \mathrm{MeV})$} \\
\hline $\begin{array}{l}\text { Unirradiated, L-T } \\
\text { Irradiated, estimated } \\
\text { Irradiated/annealed, L-T } \\
\text { Irradiated/annealed, L-T }\end{array}$ & $\begin{array}{l}343 \\
454\end{array}$ & $\begin{array}{l}168 \\
168\end{array}$ & $\begin{array}{l}164 \\
140 \\
166 \\
190\end{array}$ & $\begin{array}{l}159 \\
174\end{array}$ & $\begin{array}{r}-7 \\
-16\end{array}$ \\
\hline
\end{tabular}




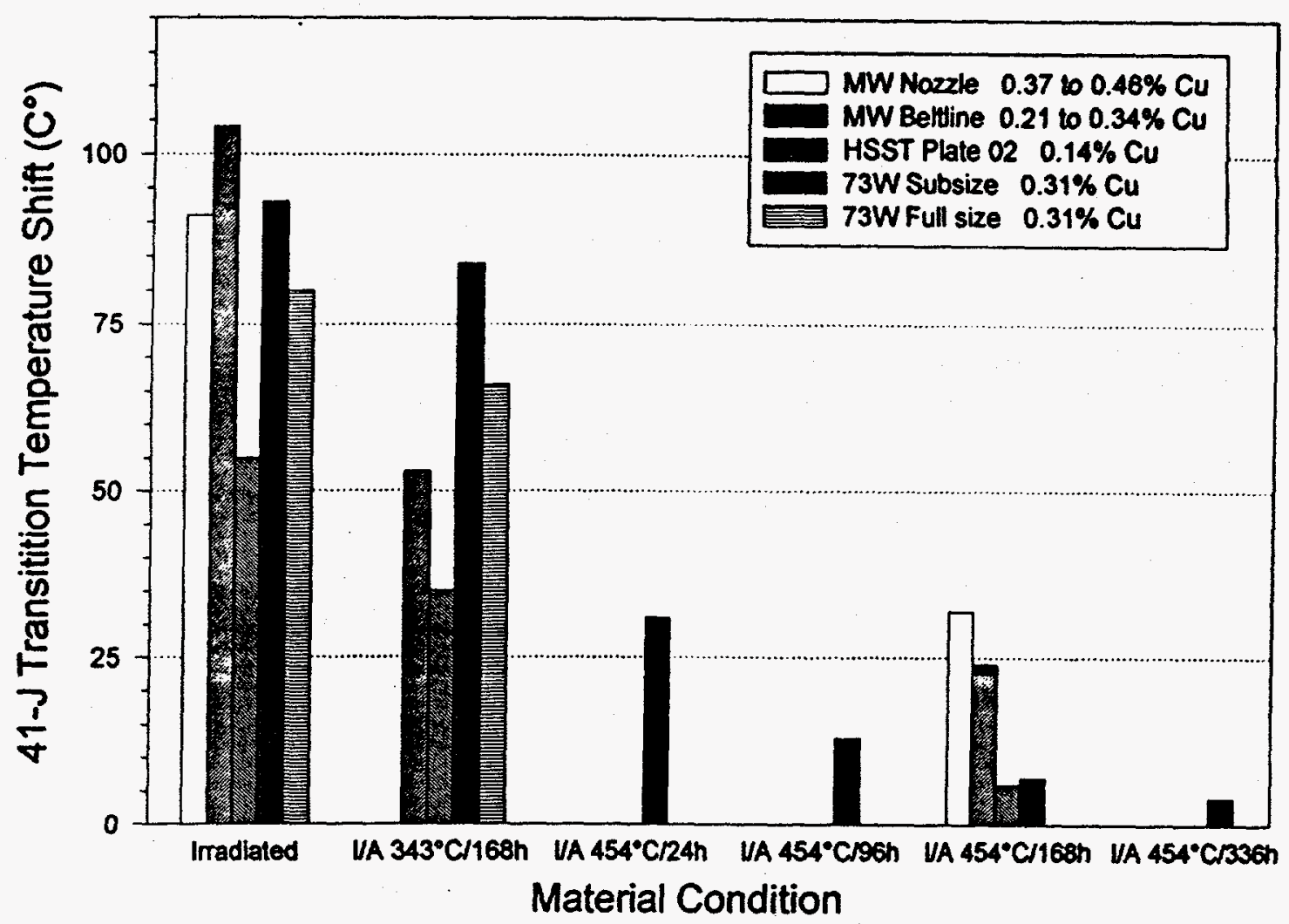

Fig. 3. The Charpy 41-J transition temperature shift for the various materials tested in the unirradiated, irradiated, and irradiated/annealed conditions.

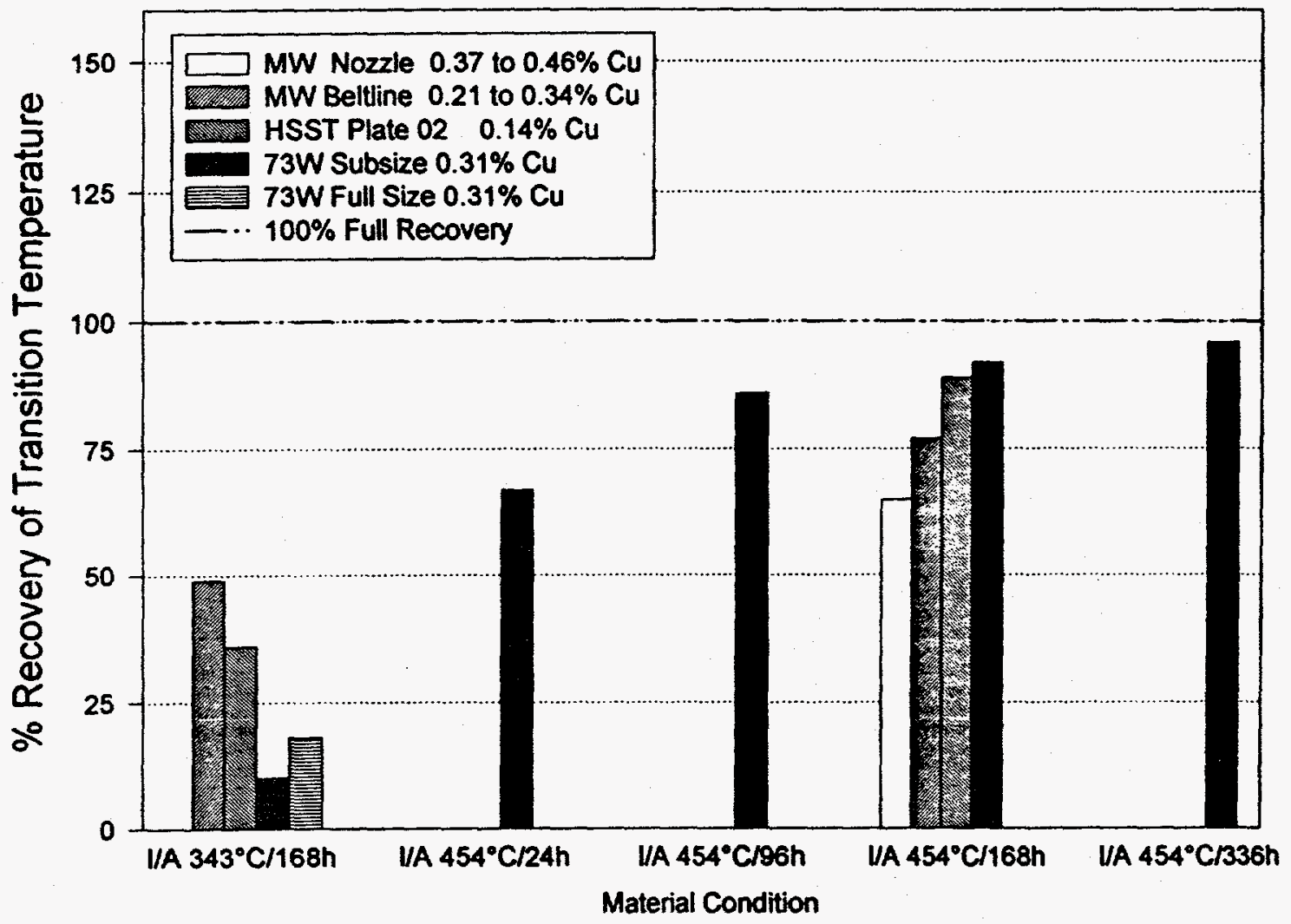

Fig. 4. Percent recovery of the Charpy transition temperature shift due to annealing. 


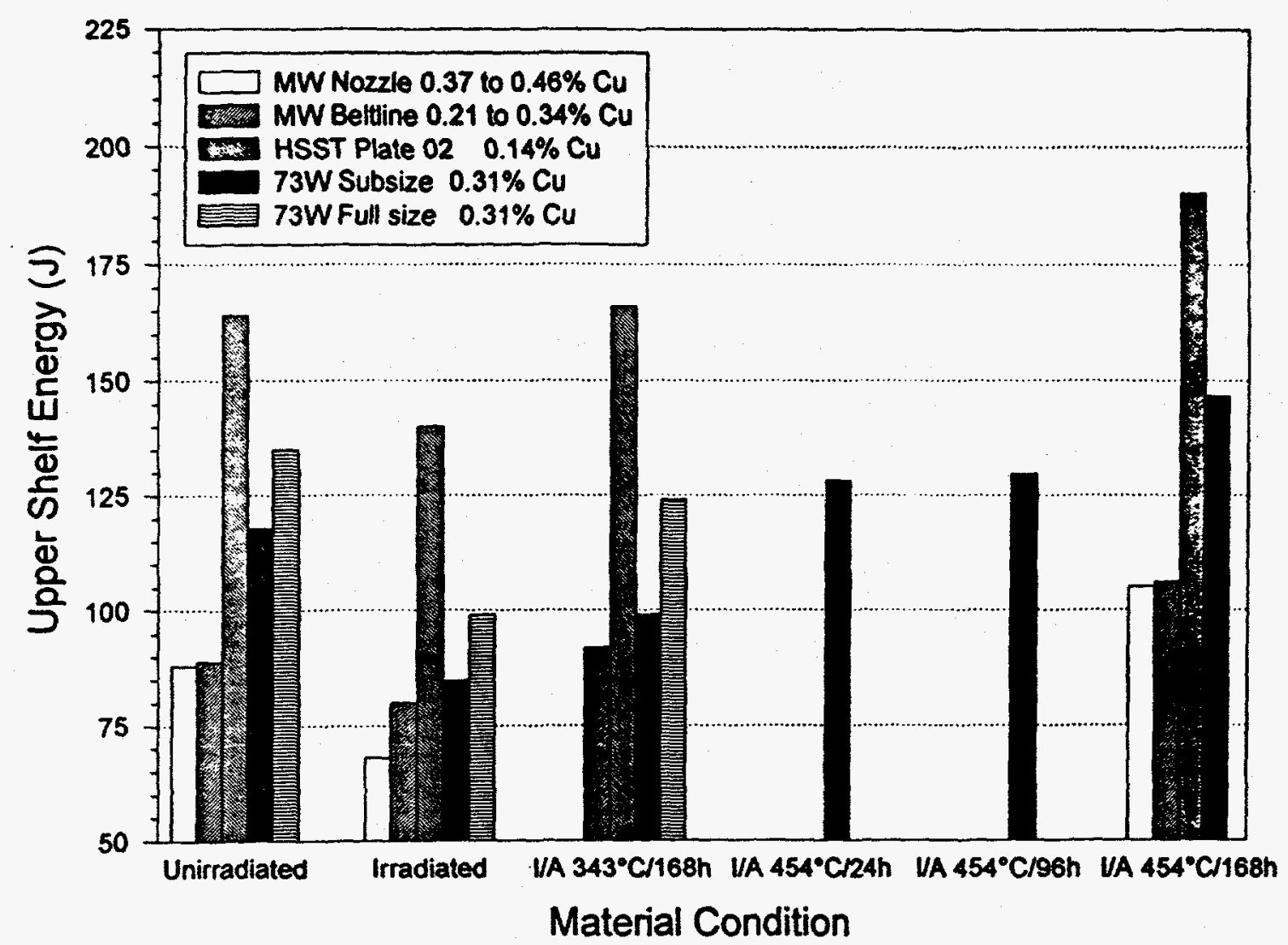

Fig. 5. The Charpy upper-shelf energy for the various materials tested in the unirradiated, irradiated, and irradiated/annealed conditions.

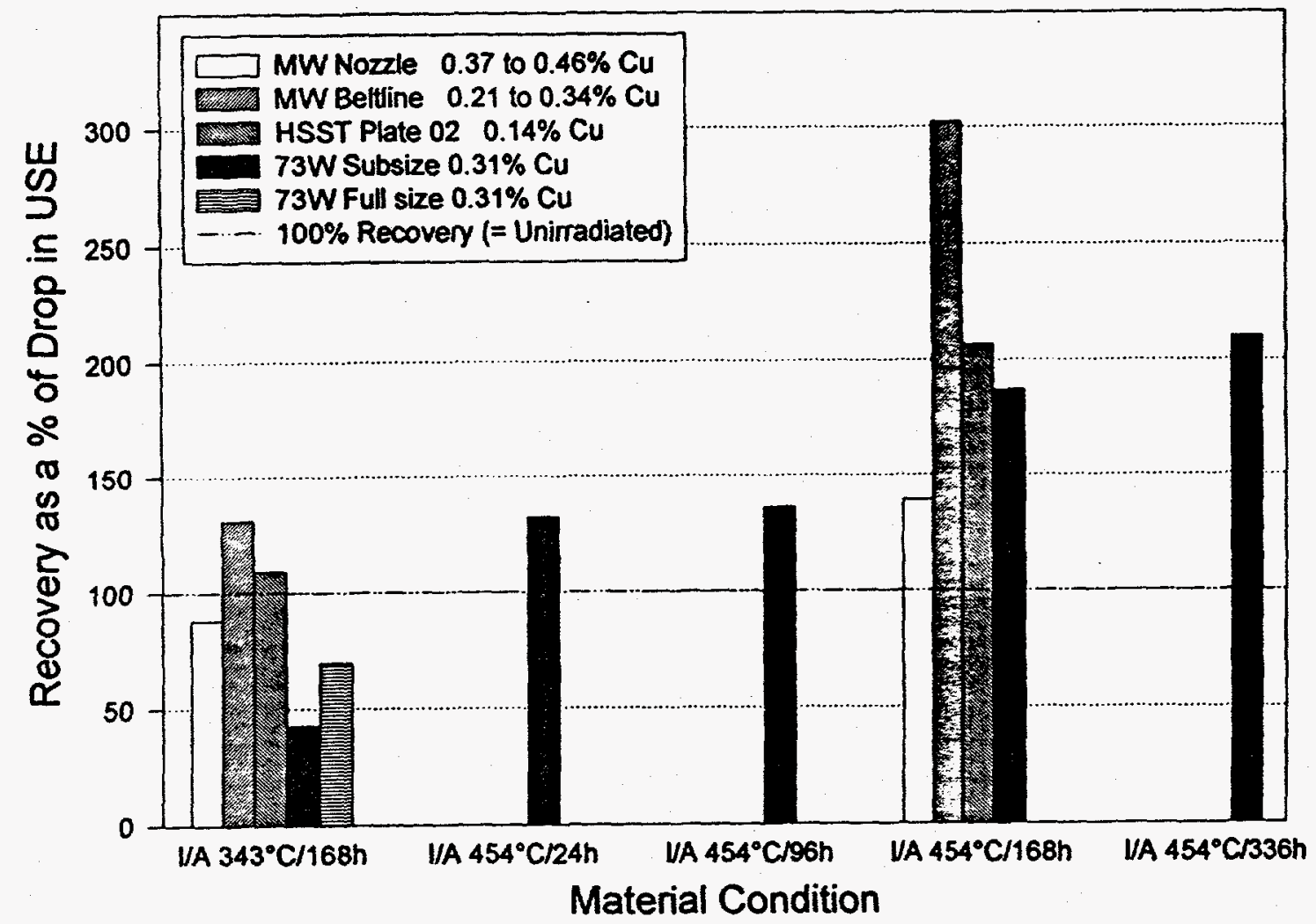

Fig. 6. Recovery as a percentage of Charpy drop in upper-shelf energy for the various materials tested in the unirradiated, irradiated, and irradiated/annealed conditions. 


$$
a_{1}=1+0.0151 \ln \left(t_{1}\right)-0.424 \mathrm{Cu}^{1\left(3.28-0.00306 T_{2}\right)} \text {, }
$$

where $t_{4}$ and $T_{a}$ are the annealing time and temperature in hours and ' $F$, respectively, and $\mathrm{Cu}^{\prime}$, in $\mathrm{wt} \%$, is the lesser of the measured copper content and $0.30 \%$, and

$$
a_{2}=0.584 T_{i}-15.5 \ln (\phi)+833, T_{2} \leq 750^{\circ} \mathrm{F},
$$

or

$$
a_{2}=0.584\left(T_{j}+637\right), T_{,} \geq 850^{\circ} \mathrm{F} \text {, }
$$

in which $\phi$, the flux, is in units of $n /\left(\mathrm{cm}^{2}-8\right)$, and $T_{1}$ is the irradiation temperature in ${ }^{\circ} \mathrm{F}$. The standard error is approximately $9.4^{\circ} \mathrm{C}$. The values prodicted by Eqs. (6) through (9) are given in Table 3, together with the difference between the prodicted and experimental values. Both latter values have been plotted in Figs. 7 and 8 . It may be noted that, due to the variation in copper content in the Midland weld, a range of values was calculated corresponding to the range in measured copper content. The range of predicted values has also been indicated in Figs. 7 and 8 . It may be seen that the values predicted by the model all fill within \pm 2 standard crors, except for the $M W$ material annealed $343^{\circ} \mathrm{C}$ for $168 \mathrm{~h}$, which is over predicted.

The Eason et al. model to predict the recovery of the USE is

$$
\text { USE }=U E_{2}+\left[1-0.586 \exp \left(\frac{-t_{2}}{15.9}\right)\right] \times
$$

$$
\left[0.570 \Delta \mathrm{USE}_{1}+\left(0.120 \mathrm{~T}_{\mathrm{q}}-104\right) \mathrm{Cu}+0.0389 \mathrm{~T}_{\mathrm{q}}-17.6\right] \text {. }
$$

where the USE is in $\mathrm{AHb}$, the subscripts and the remaining parameters are as defined previously. It should be noted that the copper in Eq. (10) is the measured copper content in wt \%. The standard error for Eq. (10) is $6.9 \mathrm{~J}$. The predicted USE, together with the difference between the predicted and measured values, are given in Table 4. These values have also been plotted in Figs. 9 and 10. The predicted values are generally within \pm 2 standard errors, except for HSSI weld $73 \mathrm{~W}$ annealed at $454^{\circ} \mathrm{C}$ for 168 and $336 \mathrm{~h}$, which Eq. (10) underpredicted the recovery of the USE.

The rate of toughness degradation of irradiated and annealed RPV steels upon reirradiation is the present focus of investigations at ORNL. This is a major consideration in determining how long an RPV could be operated safely after it is annealed. It is possible that for some of the older RPVs for which annealing will be considered no archival material will be available, and the surveillance data from CVN specimens are the only data available that describe the rate of cmbrittlement. Thus, relating the rate of toughness degradation due to reirradiation to the rate of transition temperature shift of CVN specimens (the so-called "trend curve") from the unirradiated state becomes important.

\section{CONCLUSIONS}

Specimens from irradiated submerged-are welds and a plate material were annealed at two temperatures for various lengths of time. The following conclusions could be deduced from the results:

1. Annealing has resulted in various degrees of recovery of the transition temperature and USE that depend strongly upon the annealing temperature and to a somewhat lesser degree upon the annealing time.

2. Recovery at the lower annealing temperature investigated, $343^{\circ} \mathrm{C}$ and for the $168 \mathrm{~h}$ annealing time has resulted in recovering most of the USE, but the recovery of the $T T_{41.1}$ varied from insignificant to substantial, depending upon the material.

3. For the materials investigated, there appears to be a relationship between the recovery of the $\mathrm{TT}_{41 . \sqrt{.}}$ and the recovery of the USE, in that the materials that recovered a substantial portion of the $T T_{41 \sqrt{ }}$ also recovered the USE to a significant degree. Thus it appears that if the transition temperature recovers, this indicates a high likelihood that the USE will also recover to a significant degree.

4. The percentage recovery of the USE was always greater than the percentage recovery of the Charpy TT.

Research performed to date used previously irradiated material. More studies are noeded to determine the fracture toughness behavior and its relationship to the Charpy TT and USE during reirradiation after annealing at several temperatures and for different lengths of time. With regard to the potential use of $343^{\circ} \mathrm{C}$ as an annealing temperature, the results from the materials investigated show that, in some cases, the recovery of the $\mathrm{TT}_{i}$ was insignificant, but in others it was approximately $50 \%$. It is believed that the subsequent reembrittlement rate should be investigated, as it is possible that it may be small enough that further embrittlement will be significantly retarded. Such a low annealing temperature could then be used for vessels that have not yet reached the screening criteri2.

\section{ACKNOWLEDGMENTS}

This research was sponsored by the Office of Nuclear Regulatory Research, Division of Engineering Technology, U.S. Nuclear Regulatory Commission, under Interagency Agreement DOE 1886-8109-8L with the U.S. Department of Energy under contract DE-AC05-96OR22464 with Lockheed Martin Energy Research Corp. The authors gratefully acknowledge the financial support and encouragement provided by the U.S. Nuclear Regulatory Commission, particularly Alfred Taboada and Michael G. Vassilaros, the previous and present Heavy-Section Steel Irradiation Program Monitors, respectively. The authors also wish to thank Emie D. Eason and J. E. Wright for their assistance; thanks are also due to Donald E. MaCabe, David J. Alexander, and the ASME reviewers for their helpful comments, and Julia L. Bishop for preparation of the camera-ready manuscript. 


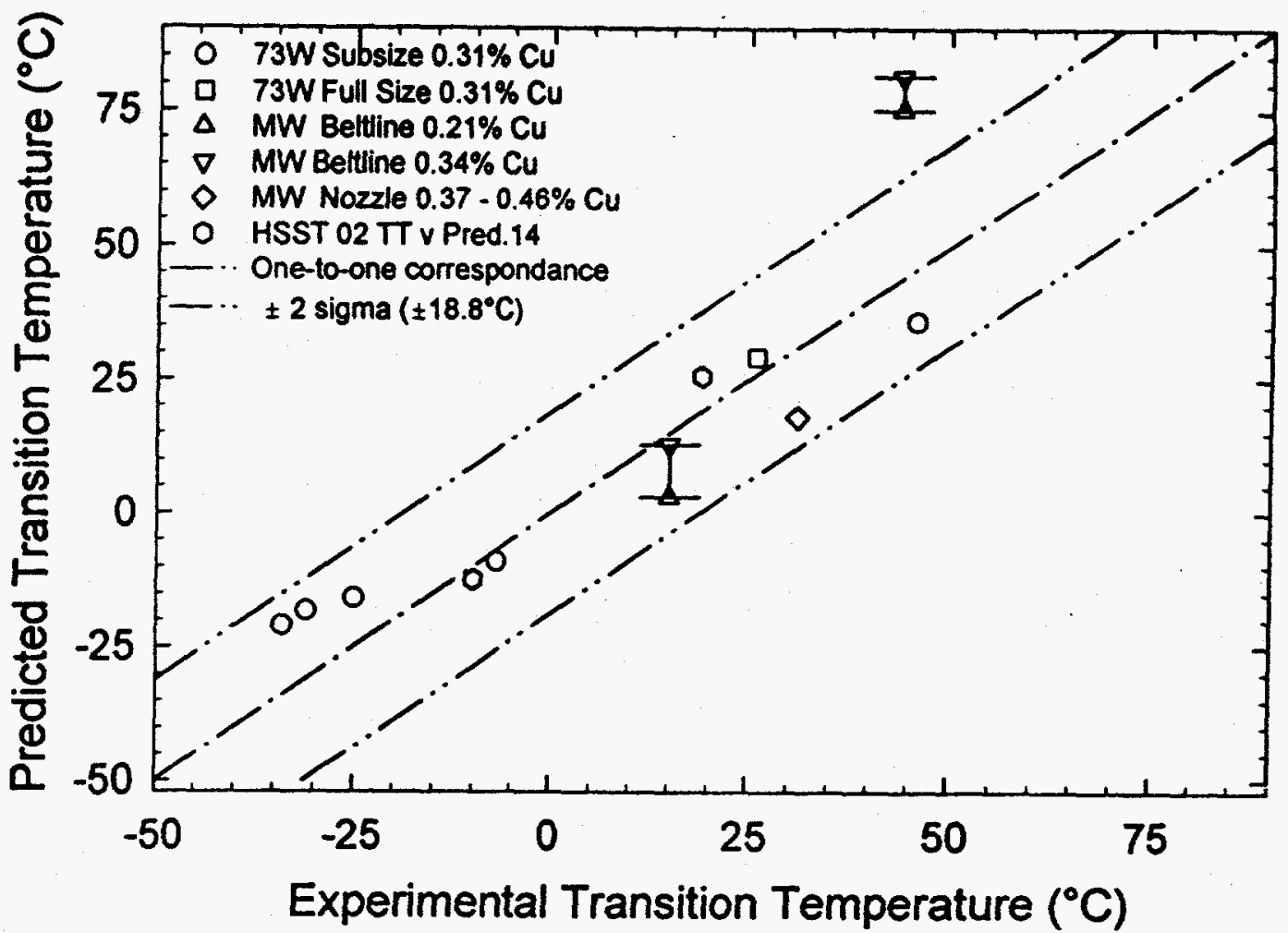

Fig. 7. Comparison of the predicted to the experimental Charpy transition temperature for the various materials tested in the unirradiated, irradiated, and irradiated/annealed conditions.

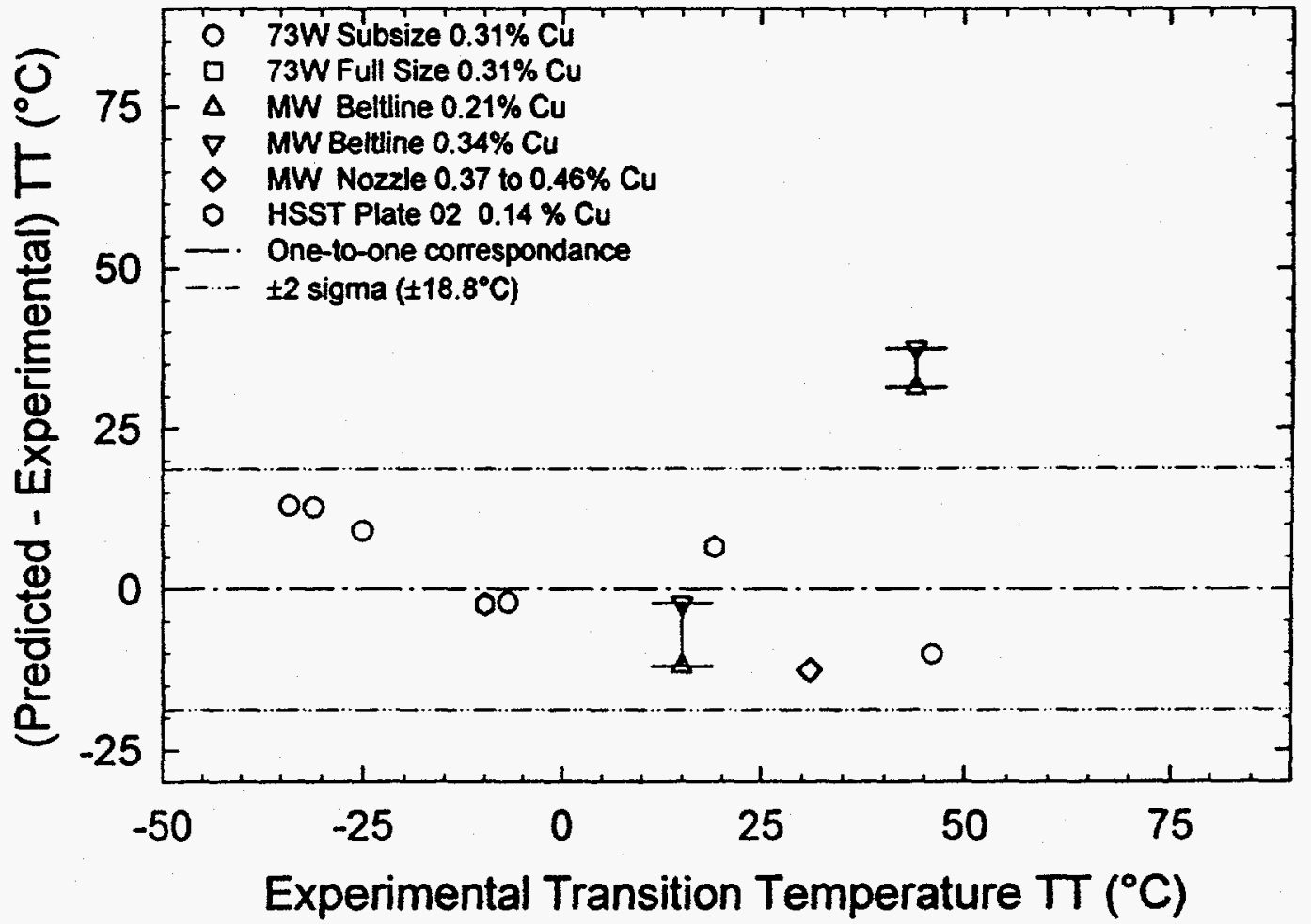

Fig. 8. Residuals of the predicted minus the experimental Charpy transition temperature for the various materials tested in the unirradiated, irradiated, and irradiated/annealed conditions. 


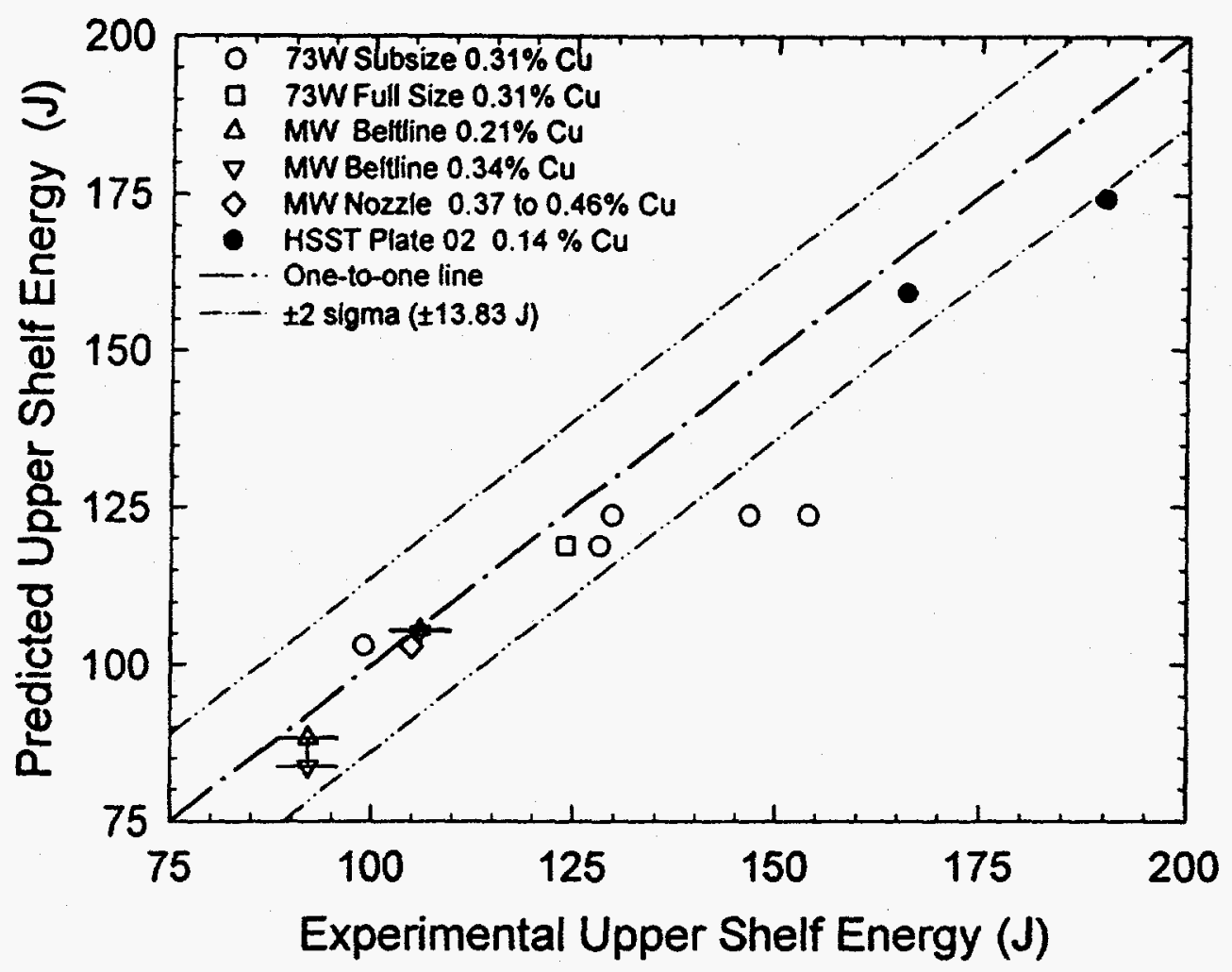

Fig. 9. Comparison of the prodictod to the experimental Chapy upper-shelf energy for the various materials tested in the unirradiated, irradiated, and irradiated/annealed conditions.

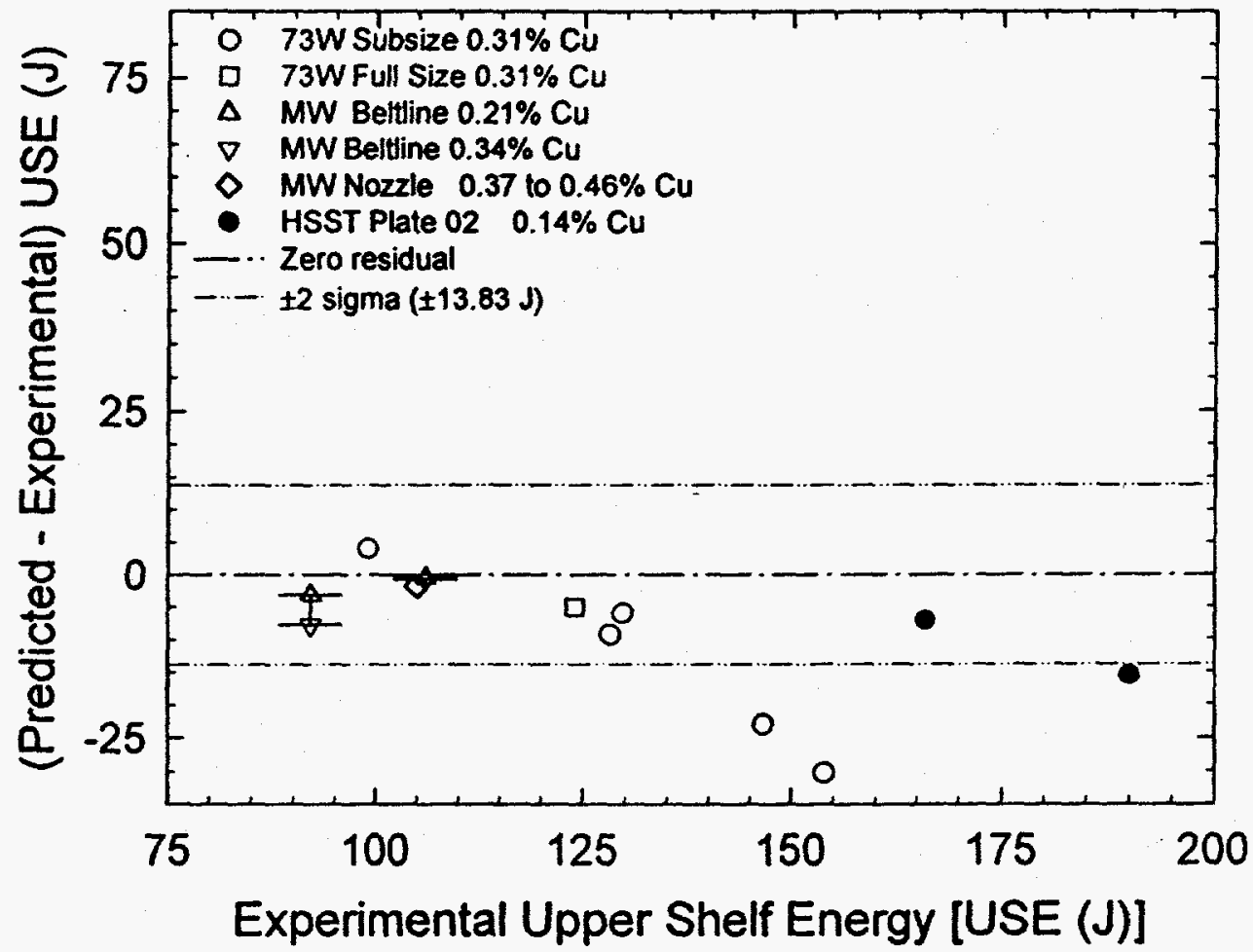

Fig. 10. Residuals of the predicted minus the experimental Charpy upper-shelf energy for the various materials tested in the unirradiated, irradiated, and irradiated/annealed conditions. 


\section{REFERENCES}

10CFR50, "Title 10," Code of Federal Regulations, Part 50, US. Govermment Printing Office, Washington, D.C., published yearly.

.10CFR50.66, "Thermal Annealing Rule," Federal Register, Vol. 59, No. 191, October 4, 1994.

ASME Boiler and Pressure Code, An American National Standard, 1992 Addenda, Section XI, Article A-4000, American Society of Mechanical Engineers, New York, December 31, 1992.

Eason, E. D., Wright, J. E., Nelson, E. E., Odette, G. R., and Mader, E. V.Modeling and Computing Services Boulder, Colo., Models for Embrittlement Recovery Due to Arnealing of Reactor Pressure Vessel Steels, USNRC Report NUREG/CR-6327 (MCS 950302), May 1995.

Iskander, S. K., Sokolov, M. A., and Nanstad, R. K. "Effects of Annealing Time on the Recovery of Charpy V-Notch Properties of Irradiated High-Copper Weld Metal," Effects of Radiation on Materials: 17th Volume, STP 1270, David S. Gelles, Randy K. Nanstad, Arvind S. Kumar, and Edward A. Little, Editors, American Society for Testing and Materials, Philsdelphis, 1996.

Major, T. R., and Lott, R. G., Thermal Annealing of an Embrittled Resesor Pressure Vessel, EPRI NP-6113-M, Electric Power Research Institute, Palo Alto, Calif., January 1989.

MoCabe, D. E., Nanstad, R. K., Iskander, S. K., and Swain, R. L., Martin Marietta Energy Systems, Inc., Oak Ridge Natl. Lab., Unirradiated Material Properties of Midland Weld WF-70, USNRC Report NUREG/CR-6249 (ORNL/TM-12777), Octobet 1994.

Milex, L. F., Baldwin, C. A., Stallman, F. W., Stallmann, and Kam, F. B. K., Martin Marietta Energy Systems, Inc., Oak Ridge Natl. Lab., Neutron Exposure Parameters for the Metallurgical Test Specimens in the Fifth Heany Section Steel Irradiation Series Capsules, USNRC Report NUREG/CR-5019 (ORNL/TM-10582), March 1988.

Nanstad, R. K., McCabe, D. E., Menke, B. H., Iskander, S. K. Iskander, and Haggag, F. M., Tffects of Irradiation on $\mathrm{K}_{\mathbf{k}}$ Curves for High-Copper Welds, "pp. 214-233 in Effects of Radiation on Malerials, 14th Intemational Symposixm, (Volvone II), ASTM STP 1046, N. H Packan, R. E. Stolke, and A. S. Kumar, Editors, American Society for Testing and Materials, Philadelphia, 1990.
Nanstad, R. K. MoCabe, D. E., Swain, R. L., and Miller, M. K. Martin Marietta Energy Systems, Inc., Oak Ridge Natl. Lab., Chemical Compasition and $R T_{\text {Nor }}$ Determinations for Midland Weld WF-70, USNRC Report NUREG/CR-5914 (ORNL-6740), December 1992.

Rogov, M., and Morozov, S., "Annealing Application Experience to Extend Reactor Vessel Life," pp. 13-113 to 13-127 in Proceedings of the DOESNLEPRI Sponsored Reactor Pressure Vessel Thermal Annealing Workshop, Vol. 2, SAND94-1515/2, Sandia National Laboratories, Albuquerque, New Mexico, 1994.

Stelzman, W. J., Berggren, R. G., and Jones, Jr., T. N., Martin Marietta Energy Systems, Inc., Oak Ridge Natl. Lab., ORNL Characterization of Heanysection Steel Technology Program Plates 01, 02, 03, USNRC Report NUREG/CR-4092 (ORNL/TM-9491), April 1985.

Sokolov, M. A., McCabe, D. E., Nanstad, R. K and Iskander, S. K., "Comparison of Fracture Toughness and Charpy Impact Properties Recovery by Thermal Annealing of Irradiated Reactor Pressure Vessel Steels," pp. 771-782 in Proceedings of the Seventh International Sympaxium on Environmental Degradation of Materials in Nuclear Power Systems - Water Reactors, Geoffrey Airey et al, Editors, Breckenridge, Colorado, August 1995.

Sokolov, M. A., Nanstad, R. K and Iskander, S. K., "The Effect of Thermal Annealing on the Fracture Toughness of Low Upper-Shelf Welds," Effects of Radiation on Materials: 17th Volume, STP 1270, David S. Gelles, Randy K. Nanstad, Arvind S. Kumar, and Edward A. Little, Editors, American Society for Testing and Materials, Philadelphia, 1996.

Wallin, K, "Recommendations for the Application of Fracture Toughness Data for Structural Integrity Assessments," pp. 465-495 in Proceetings of the Joint LAEACSNI Specialists' meeting on Fracture Mechanics Verification by Large-Scale Testing, NUREG/CP-0131 (ORNLTM-12413), October 1993. 